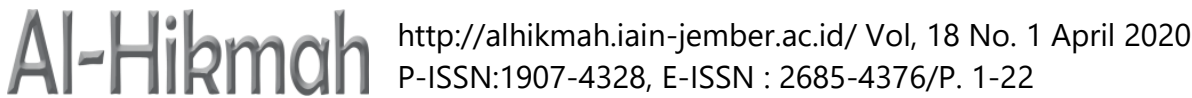

\section{الارهاب ومفهومه المعاصر واسبابه وسبل مواجهته}

\section{عبدالودود نفيس}

الجامعة الاسلامية الحكومية جمبر

nafiswadud@yahoo.com

\section{ملخص البحث}

الإرهاب هو رعب تحدثه أعمال عنف كالقتل وإلقاء المتفجرات أو التخريب لإقامة سلطة أو تقويض أخرى. والإرهابيونْ وصف يطلق على الذين يسلكون سبيل العنف والإرهاب لتحقيق أهدافهم السياسية.

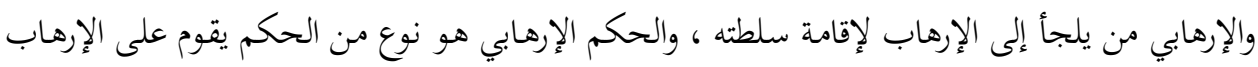

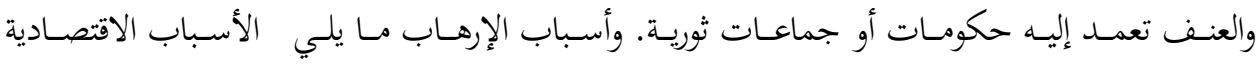
والاجتماعية وغياب العدالة الاجتماعية, والظروف السياسية وتضييق دائرة الشورى والديمقراطية أو انعدامها,

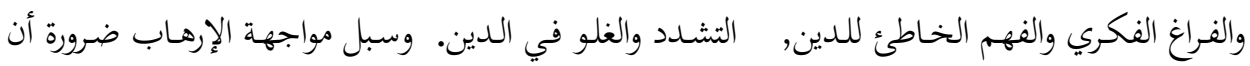

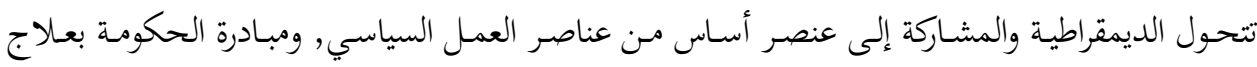

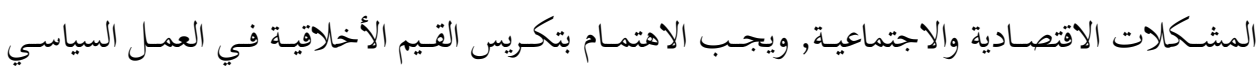

$$
\text { والإسلامي. }
$$

الكلمات الرائسية: الإرهاب والإرهابي والحكم الإرهابي وعبدالودود نفيس

\section{التمهيل}

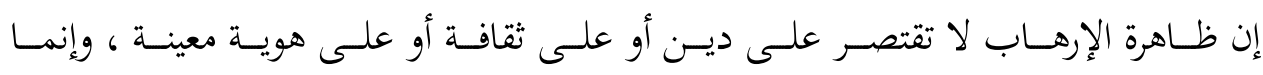

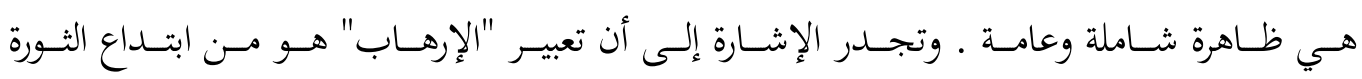

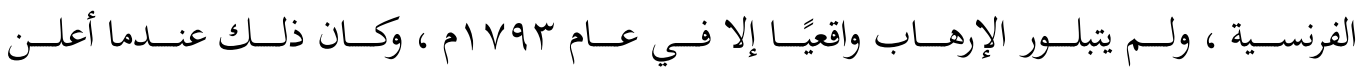

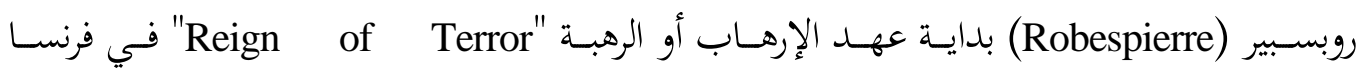

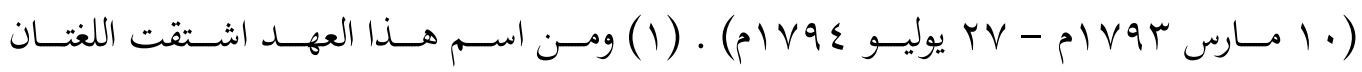
الإنجليزيــة والفرنســية كلمــة (Terrorism) بالإنجليزيــة و (Terrorisme) بالفرنسـية ، بمعنسى 
Al-Hikmah. Vol, 18 No. 1 April 2020

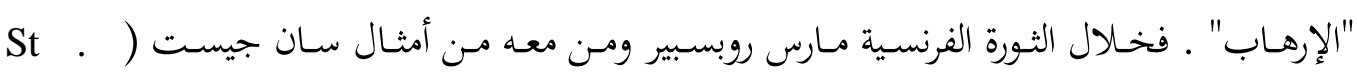
وكوثـون (Cust) (Couthon) العنـف السياسـي على أوسـع نطـاق ، حيـث قـادوا حملـة إعـــام

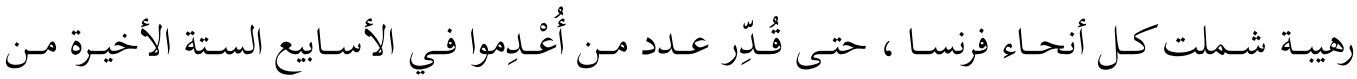
عهد الإرهاب ج7 با مواطنًا فرنسيًا من الجنسين في باريس وحدها ومسن أصـل سـكان فرنسـا ، الــين كـان يبـغ عـددهم في ذلك الوقـت VV مليـون نسـمة

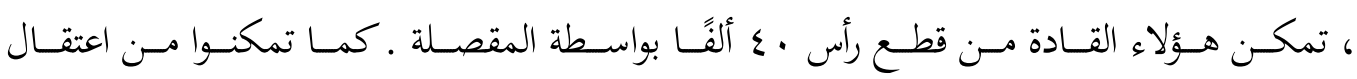

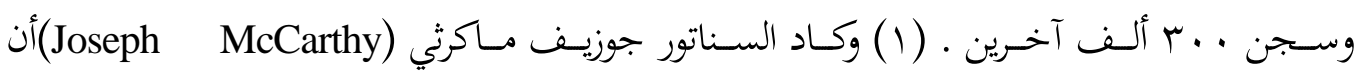

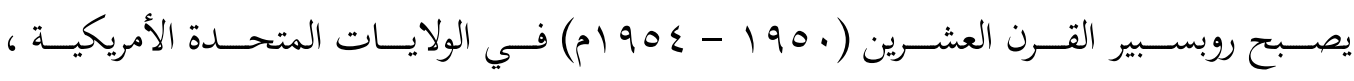

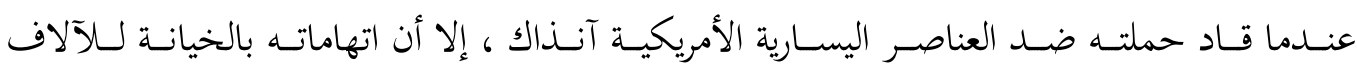
لم تصل إلى حدِّ قطع رؤوسهم بالمقصلة أو خنقهم في غرف الغاز المغلقة. 1 ويمكـن تجسـيد هـذا الاخـتلاف في العبـارة المختصـرة التـي تقـول :"إن الإرهـابي في نظـر الـبعض ، هــو محــارب مـن أجــل الحريسة فـي نظـر الآخـرين" . وأدى ذلـك إلـى فشـل أغلـب الجهـود الدوليـة فـي الوصـول إلىى تحديـــ دقيـق لحقيقــة الإرهــاب ، ممــا حــال دون الاتفــاق علـى درجــة مــن التعـاون الـدولي لمكافحــة الإرهـاب ، لدرجــة أن المـؤتمر الــدولي

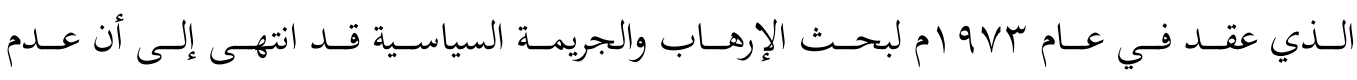
وجـود مفهـوم واضـح للأسـباب التسي تـؤدي إلى ممارسـة النشـاطات التـي تنشـئ حالـة الإرهـاب هو العقبة التي تحول دون اقتلاع الإرهاب واجتثاث جذوره . ويختلـف الوصـف الـــي يطلقــه رجــال الإعــلام علـى أعضــاء المنظمــات الإرهابيـة بـاختلاف الموقـف السياسـي الـذي يتخذونـه تجـاهـم ، ومسن ثـم اسـتخدمت أوصـاف مختلفــة

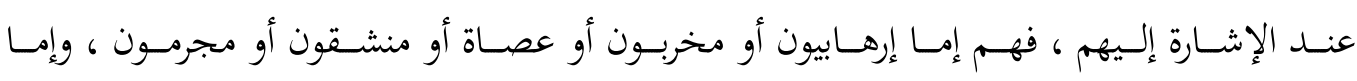

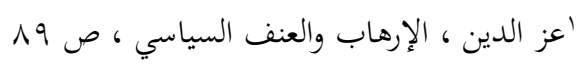

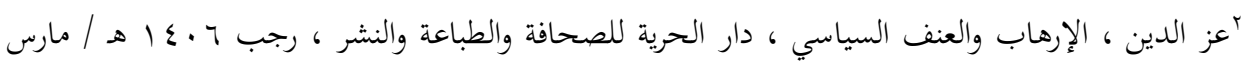




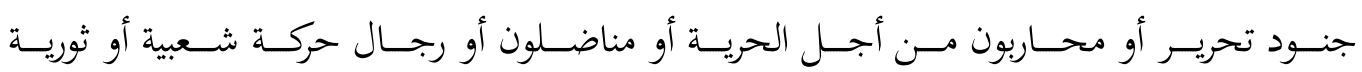
وأحيانًا يوصـفون بــأنهم خصـوم أو معارضـون للحكـــم أو "راديكــاليون" (متطرفـون: Radicals ) . وتوصـف عمليـاتهم في نظـر بعض الكتـاب بأنهـا عمليـات إرهابيـة أو أفعـال إجراميـة دنيئـة وغادرة ، وفي نظر بعضهم الآخر تعد عمليات فدائية أو عمليات مقاومة أو تحرير .

\section{المبحث الاول: تعريف الارهاب}

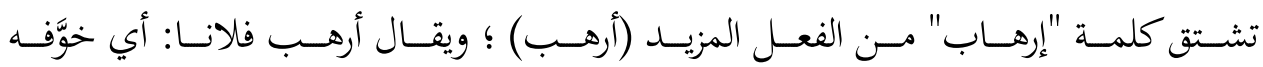

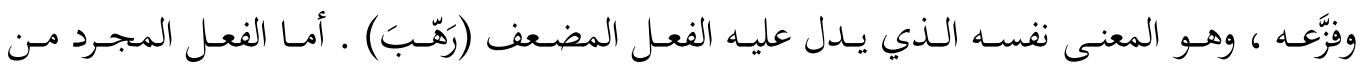

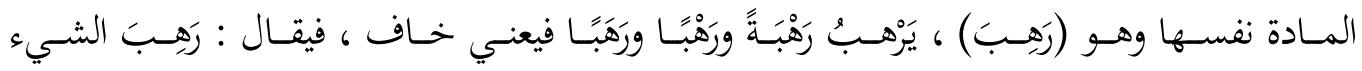

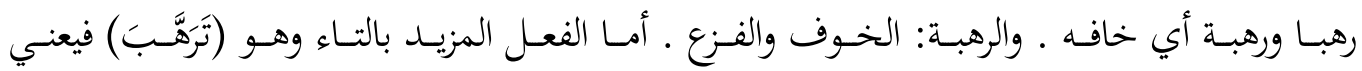

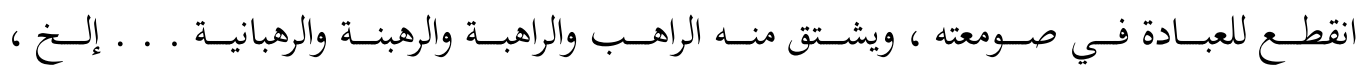

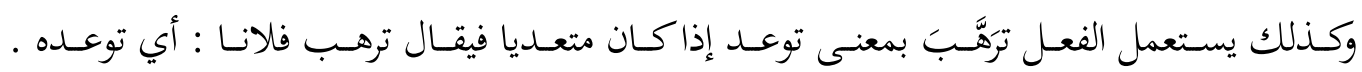

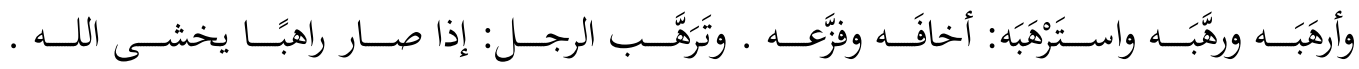

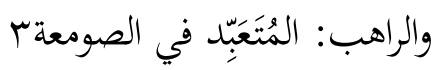

والإرهـابيون في "المعجــم الوسـيط": وصـف يطلـق علـى الـذين يســلكون سـبيل العنـف والإرهـاب لتحقيـق أهــافهم السياسـية. ؟ والإرهـابي فـي "المنجـــ": مـن يلجـأ إلى الإرهـاب

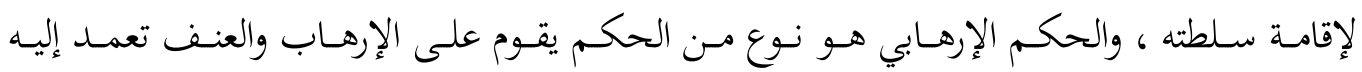

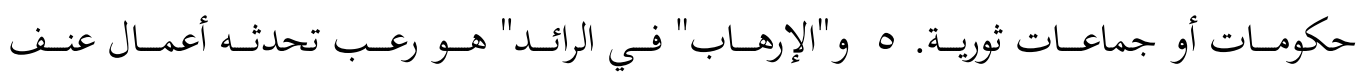

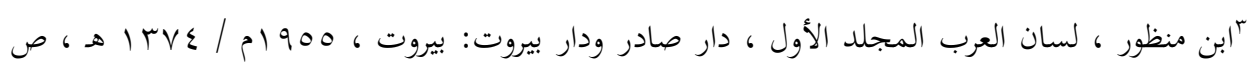
$\varepsilon r q-\varepsilon r \uparrow$

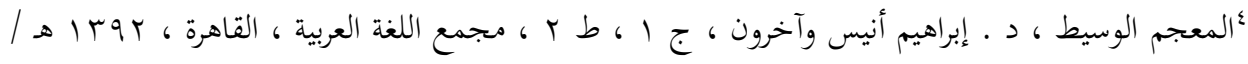
rVT ص r P I $9 V T$

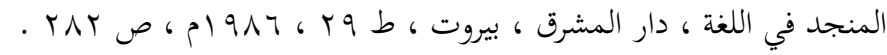

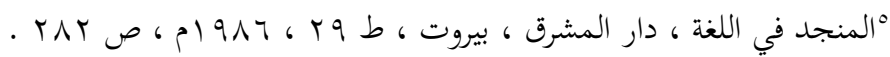


Al-Hikmah. Vol, 18 No. 1 April 2020

كالقتـل وإلقــاء المتفجـرات أو التخريــب ، و "الإرهـابي "هـــ مَـنْ يلجــأ إلـى الإرهـاب بالقتـل أو إلقـاء المتفجـرات أو التخريـبـ لإقامـة سـلطة أو تقـويض أخـرى ، و "الحكــم الإرهـابي" هـو نـوع

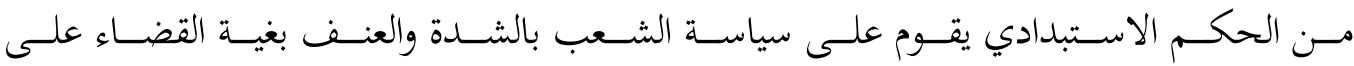
النزعـات والحركــات التحرريــة والاسـتقلالية. 7 وتجـــر الإشـارة إلـى أن المعجمــات العربيـة

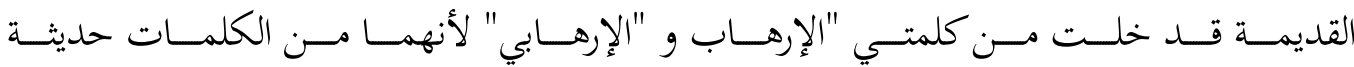

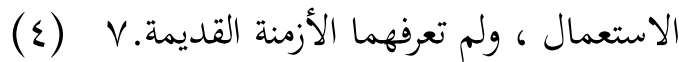

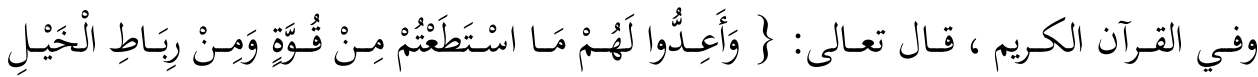

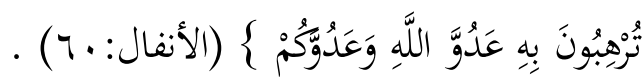

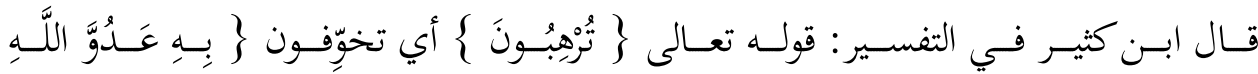

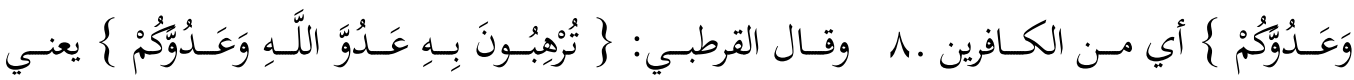
تخيفون به عدو الله وعدوكم من اليهود وقريش وكفار العرب .

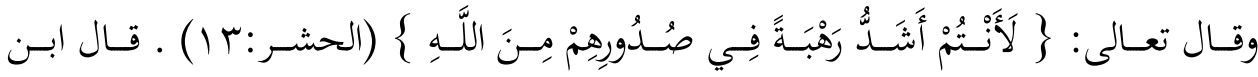
كثير في التفسير: أي يخافون منكم أكثر من خوفهم من الله .

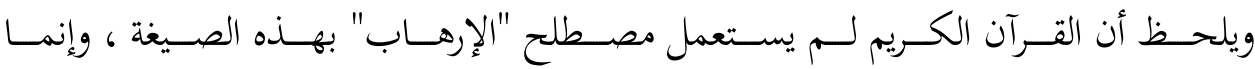
اقتصـر على اسـتعمال صـيغ مختلفــة الاشـتقاق مـن المـادة اللغويـة نفسـها ، بعضـها يــل على

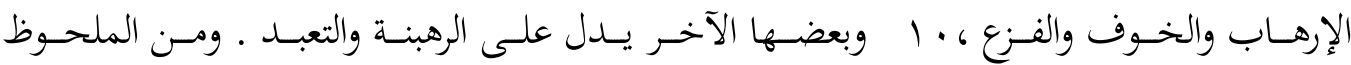

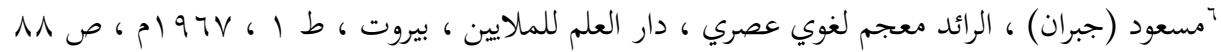

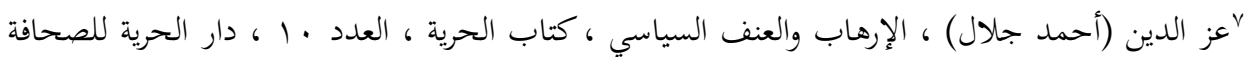

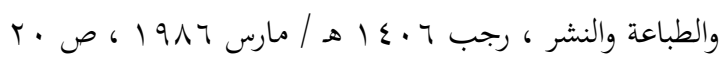

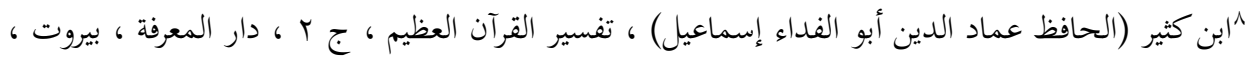

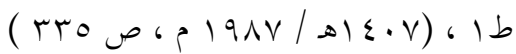
9 القرطبي (أبو عبد الله محمد بن أحمد الأنصاري) ، الجامع لأحكام القرآن ، ج ه ، ، دار إحياء التراث ،

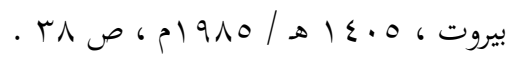
‘'المعجم المفهرس لألفاظ القرآن الكريم ، دار الأندلس ، بيروت ، (د . ت . ) ، مادة (رهب) ، ص 


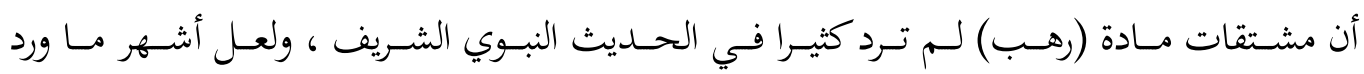

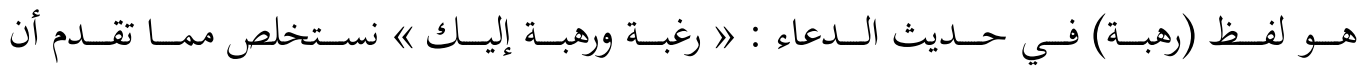

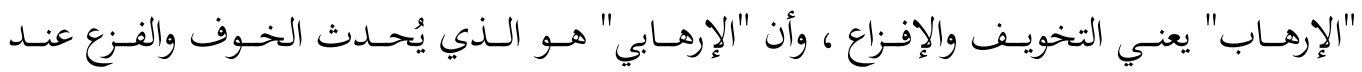

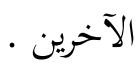

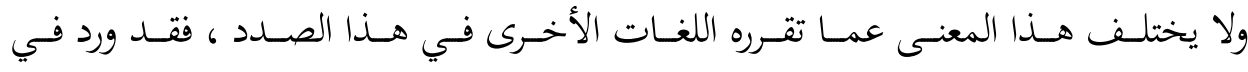

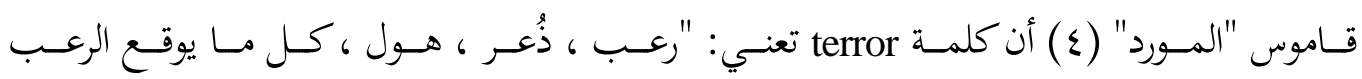
في النفـوس ، إرهـاب ، عهـــ إرهـاب" ، والاسـم terrorism يعنـي: "إرهـاب ، ذعـر ناشـئعـن

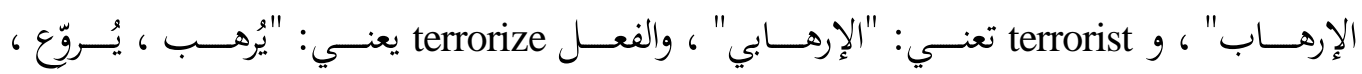

$$
\text { يُكرهه (على أمر) بالإرهاب" }
$$

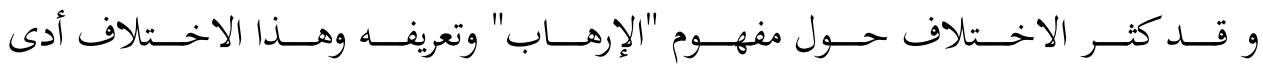

اخستلاف الـدول في نظرتهـا إلى الإرهـاب مـن حيـث مفهومـه ومعنـاه ، إلى صـوبة اتفاقهـا

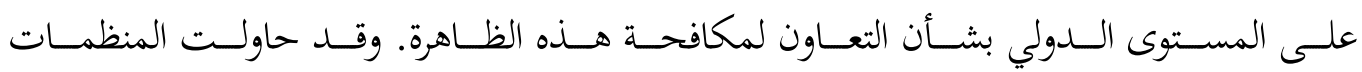

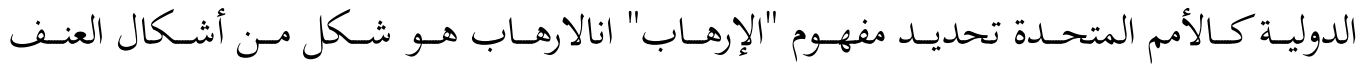
المـنظم ، بحيـتث أصسبح هنـاك اتفــاق عـالمي على كثيــر مـن صـور الأعمــال الإرهابيـة مثـل

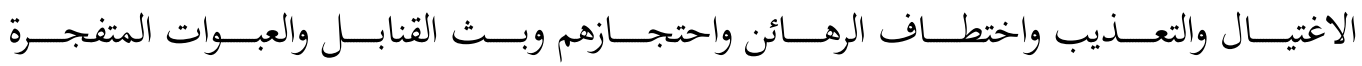
واختطــاف وســائل النقـل كالسـيارات والأتوبيسـات والطـائرات أو تفجيرهـــا ، وتلغـيم الرســائل وإرسالها إلى الأهداف التي خطط الإرهابيون للإضرار بها . . . إلخ .

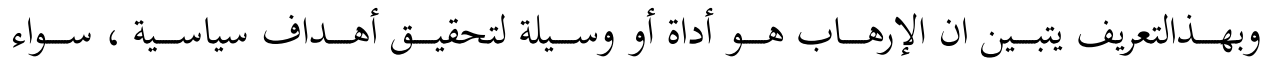

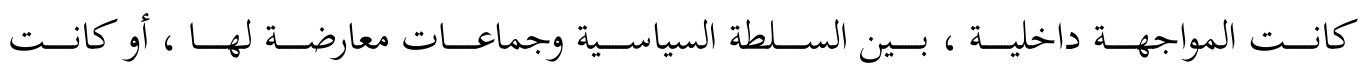
المواجهـة خارجيـة بـين الــول ـ فالإرهـاب هـو نمـط مـن أنمـاط اسـتخدام القـوة فـي الصـراع السياسـي ، حيـث تسـتهدف العمليـات الإرهابيـة القــرار السياسـي ، وذلـك بإرغــام دولــة أو

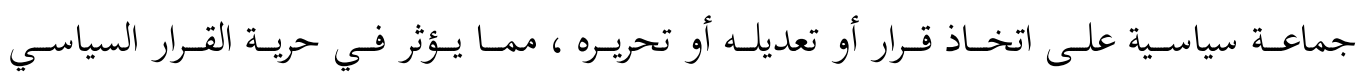

"البعلبكي (منير) ، المورد- قاموس إنكليزي عربي ، دار العلم للملايين ، بيروت ، ط اب ، و99 ام 
Al-Hikmah. Vol, 18 No. 1 April 2020

لـدى الخصـوم. والإرهـاب هـو باختصــار عبـارة عـن العمليـات الماديـة أو المعنويـة التـي تحـوي

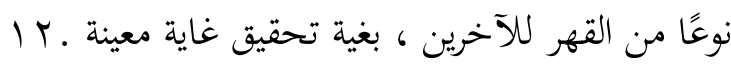

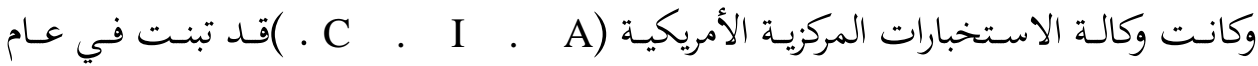

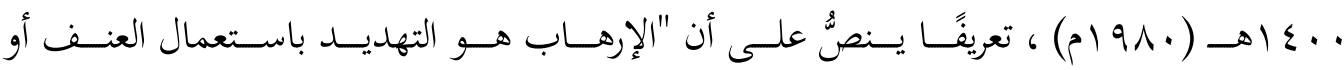

اسـتعمال العنـف لأغـراض سياسـية مـن قبـل أفـراد أو جماعــات ، سـواء تعمـل لصــالح سـلطة

حكوميـة قائمـة أو تعمـل ضــدها ، وعنــدما يكـون القصـــ مـن تلـك الأعمــال إحــداث صــدمة ،

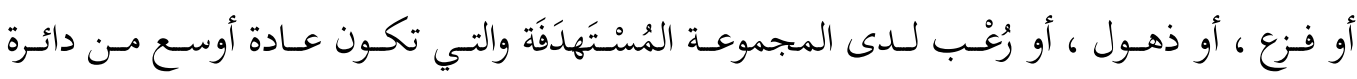
الضـحايا المباشـرين للعمـل الإرهـابي · وقـــ شـمل الإرهـاب جماعـات تسـعى إلى قلـب أنظمـة

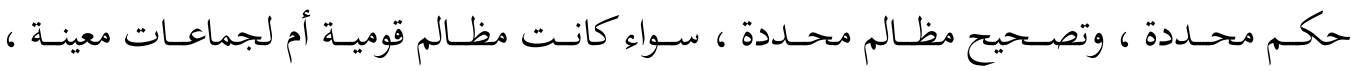
أو بهدف تدمير نظام دولي كغاية مقصودة لذاتها".

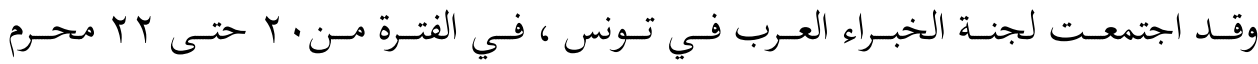

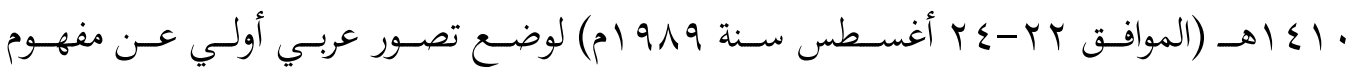

الإرهـاب والإرهـاب الـدولي والتمييـز بينـه وبـين نضـال الشـعوب مـن أجــل التحــرر ، ووضـعت

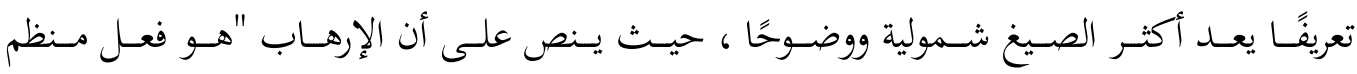

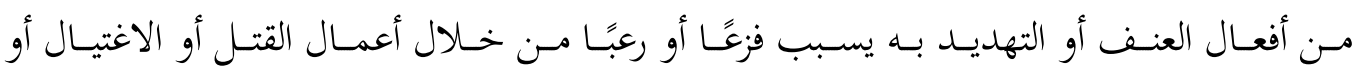
حجــز الرهـائن أو اختطـاف الطـائرات أو تفجيـر المغرقعـات وغيرهــا ممـــا يخلـق حالـة مـنـ الرعسب والفوضـى والاضــطراب ، والـذي يسـتهدف تحقيـق أهـــاف سياسـية سـواء قامست بـهـ

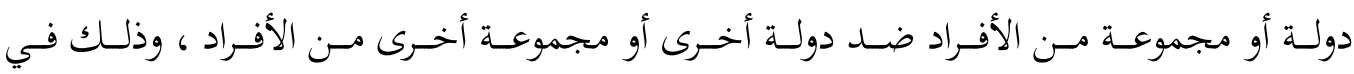
غيـر حــالات الكفــاح المســلح الـوطني المشـروع مـن أجــل التحريسر والوصـول إلى حـق تقريـر المصـير فـي مواجهــة جميـع أشـكال الهيمنــة أو قـوات اسـتعمارية أو محتلـة أو عنصــرية أو

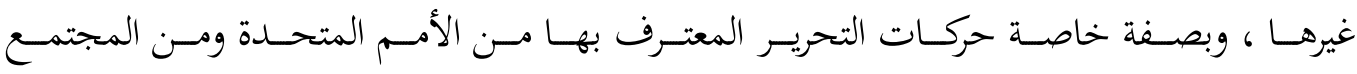

ب'الفرماوي (عبد الحي) ، الإرهاب بين الفرض والرفض في ميزان الإسلام ، دار البشير ، طنطا ، ط ا ، 


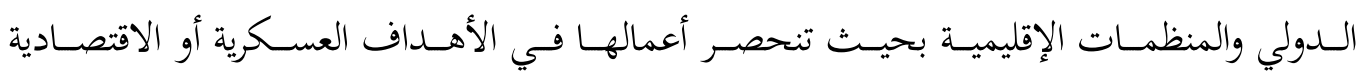
للمسـتعمر أو المحتـلـ أو العـدو ، ولا تكـــون مخالفــة لمبـادئ حقــوق الإنســان ، وأن يكــون

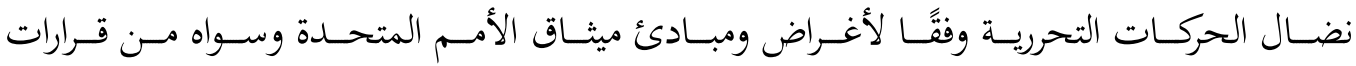
أجهزتها ذات الصلة بالموضوع".بران

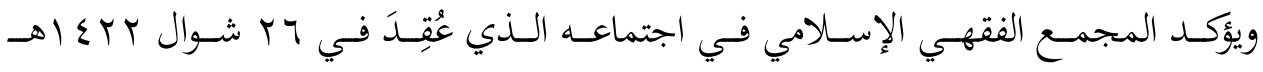

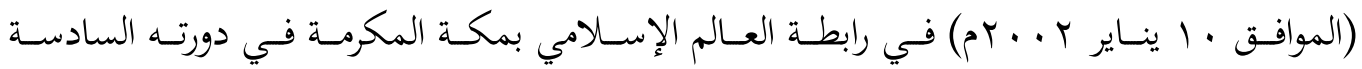
عشــة: الإرهــاب هــو العـدوان الـــي يمارسـهـ أفـراد أو جماعـات أو دول بغيَّا علـى الإنســان

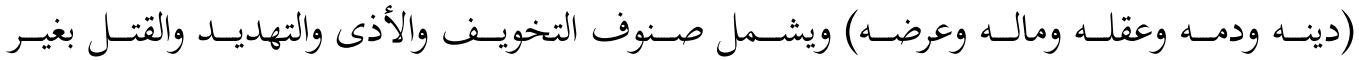
حـق ، ومــا يتصـل بصـور الحرابـة ، وإخافـة السـبيل ، وقطـع الطريـق ، وكـل فعـل مـن أفعـال

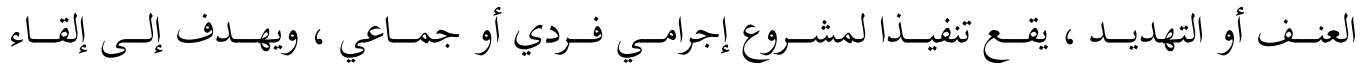

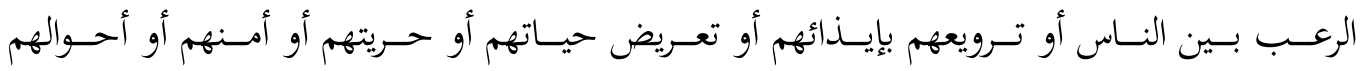

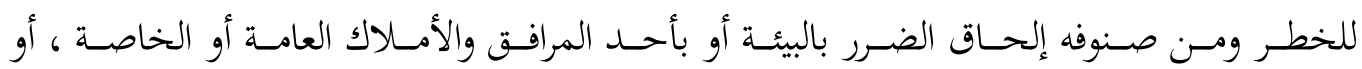
تعريض أحد الموارد الوطنية أو الطبيعية للخطر.

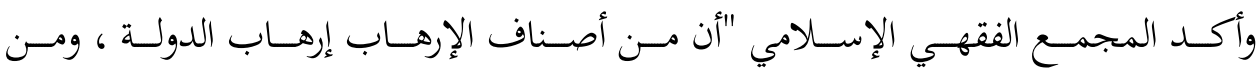

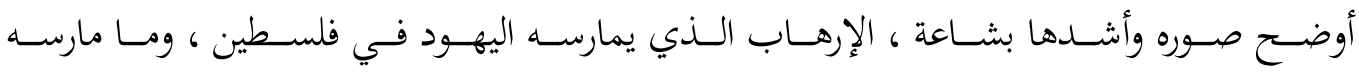

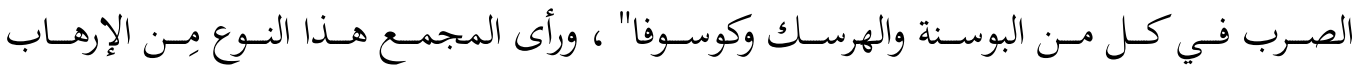

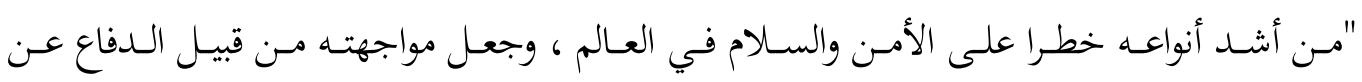
النفس والجهاد في سبيل الله" . ومــن النقـاط المهمــة فـي البيـان الإجمــاع علـى أن الإرهـاب لـيس مـــ الإســلام وأن

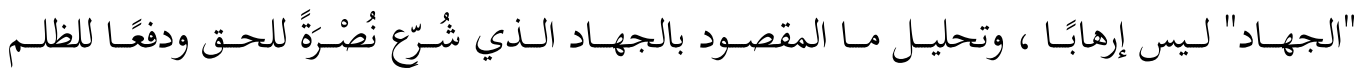

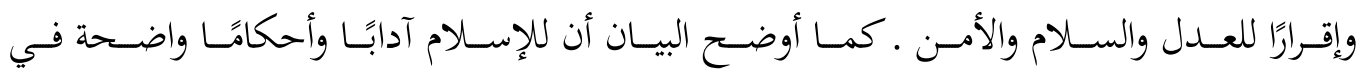

rا خالد عبيدات ، ظاهرة الإرهاب ، محاضرة نشرت في صحيفة الرأي الأردنية في عددها الصادر يوم الأربعاء 
Al-Hikmah. Vol, 18 No. 1 April 2020

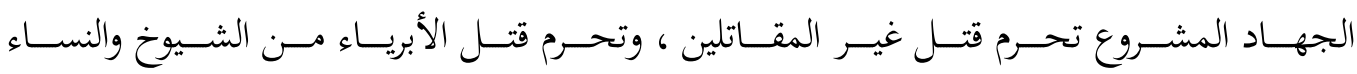
والأطفــال وتحــرم تتبـع الفـارين ، أو قتـل المستسـلمين ، أو إيـذاء الأســى ، أو التمثيـل بجثـث القتلى أو تدمير المنشآت والمواقع والمباني التي لا علاقة لها بالقتال .

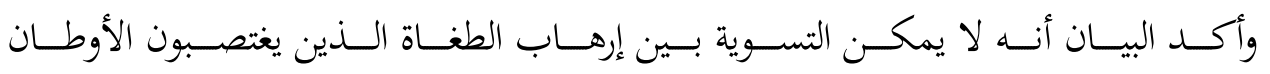
ويهــرون كرامــة الإنســان ، ويدنسـون المقدسـات وينهبـون الثــورات وبـين ممارسـة حـق الـدفاع المشروع الذي يجاهد به المستضعفون لاستخلاص حقوقهم المشروعة في تقرير المصير .

المبحث الثاني: أسباب الإرهاب

أســبـاب ظــاهرة الإفســاد فـــي الأرض باســـم الــدين (الإرهـــاب) لا شـــك أن تلــك

الأسباب كثيرة ومتشابكة ولعل من أبرزها ما يلي : ع

ا ـ الأسباب الاقتصادية والاجتماعية

أدت التغيـرات الاقتصـادية والاجتماعيـة التـي حسدثت في الـدول الاسـالاميه في الثلاثـين

ســة الأخيـرة ، إلى تكثيـف حركـة الهجــرة مـن الريـف إلى المدينـة ، وانتشــار الأحيـاء العشـوائية الفقيـرة في مــن بعـض الـدول . وقـــ ضـمت هـذه الأحيـاء العشـوائية نسـبة عاليـة مـن المتطرفين الـدينيين وذلك بفعـل عجـز بعـض سـكانها عـن التكيـف مـع قـيم المدينـة المختلفــة عـن قـيمهم الريفيــة ، وبســبب تفشـي البطالــة ، وخاصــةً بــين الشــباب ، كــان اسـتقطابهم مــن جانــب جماعات التطرف أو العنف ، أو انضمامهم التطوعي إليها ، مسألة سهلة إلى حد كبير · وتـؤثر الأزمـات الاقتصـادية فـي الطبتـات الـدنيا فـي المتــام الأول ، حيـث تعـاني بشـدة مــن تــهور ظروفهـا المعيشـية بفعـل انتشــار البطالـة وتــهور الخــدمات وظهـور طبقــة مــن

ع الحسيني (السيد محمد) ، تعقيب في 》تحديات العالم العربي في ظل المتغيرات الدولية) ، أعمال

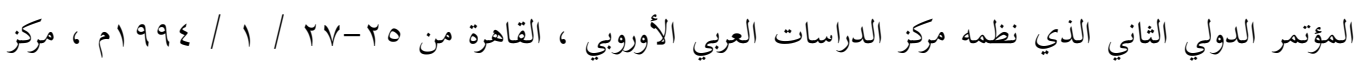

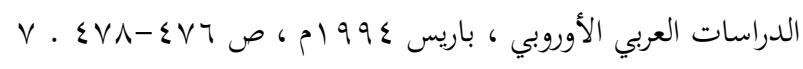

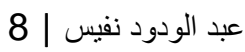




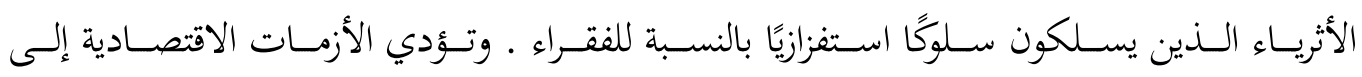
ازديـاد معـدل البطالـة والتضـخم وغـلاء الأسـعار وبالتـالي تـزداد حـــة النفــاوت الطبقي وتـنعكس آتـار هـذا الخلـل الخطيـر على الشـباب وتنشـأ تربـة صـالحة للتطـرف تـزود الجماعـات المتطرفـة بأعضاء يعانون من الإحباط ويفتقدون الشعور بالأمان والأمل في المستقبل .

\section{r ب غياب العدالة الاجتماعية}

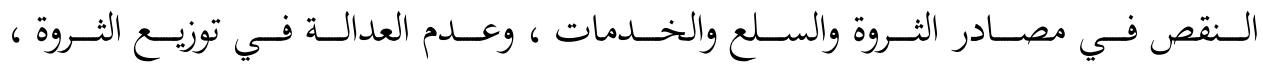
والتفــاوت فـي توزيـع الـــخول والخــدمات والمرافـق الأساسـية كــالتعليم والصـحة والإسـكان

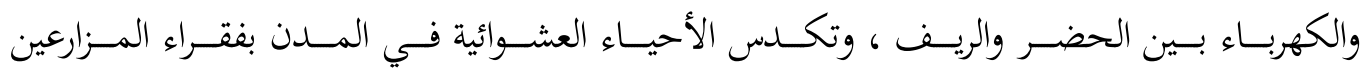

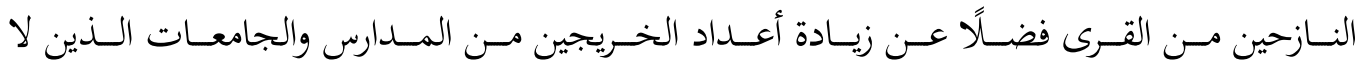
يجدون فرص العمل ، يؤدي إلى حالة من الإحباط الفردي والسخط الجماعي.

\section{r. الظروف السياسية}

تــني مسـتوى المشـاركة السياسـية ، وخاصـة بالنسـبة للشـباب ومسن مختلـف الطبقــات ، فـي اتخـاذ القـرارات التـي تمـس حيـاة المـواطن بمـا فـي ذلـك الحيـاة اليوميـة سـواء داخـل الأسـرة أو المدرســة أو الحـي السـكني أو العمـل أو عـنـ طريـق العضــية الفعالــة والنشـيطة في سي

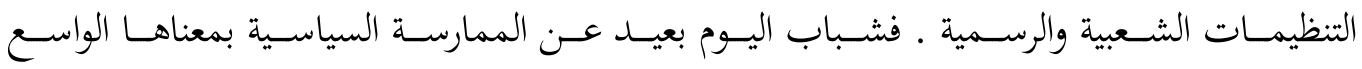
التـي تنمسي لديـه القـــرة علـى إبــاء الـرأي والحــوار حــول مســائل عامــة أو اجتماعيـة ، والتـي تعوّده على تقبل الرأي الآخر بعد تحليله ونقده والتنازل عن رأيه إذا اقتنع بغيره 1 ـ ـ

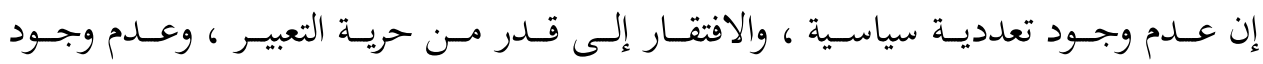
تسـداول حقيقـي للسـلطة ، يــؤدي إلـى حرمــان القـوى السياســية والاجتماعيــة مــــ التعبيـر السياسـي الشـرعي ، وإلـى تجاهـل مطالـب الأقليـات وقمـع الجماعــات المعارضــة ، ويـؤدي

10 عز الدين ، الأساليب العاجلة وطويلة الأجل لمواجهة التطرف والإرهاب في المنطقة العربية ، ص .0؛ 
Al-Hikmah. Vol, 18 No. 1 April 2020

هـذاكلـه إلى تهيئـة التربـة المناسـبة للعنـف والإرهـاب ـ ومسن أسـباب لجـوء بعـض الجماعـات الإســلامية إلى العنـف في بعـض الـدول العربيـة ، محاصـرة التيـار الـديني وقمعـه وعـدم إعطائسه حرية العمل السياسي المشروع والعلني والسماح له بالوصول إلى السلطة بطريقة سلمية .

\section{ع. تضييق دائرة الشورى والديمقراطية أو انعدامها}

لــم تأخــن غالبيـة نظم الحكـم في السباد العربيـة بمبــأ الشـورى والديمقراطيـة على الـرغم

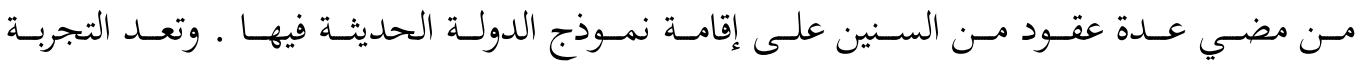
الديمقراطيـة في غالبيـة الـدول العبيـة تجربـة جديـدة وهشـة ، وربمــا تكــون شـكلية ، ولعـل أهـم

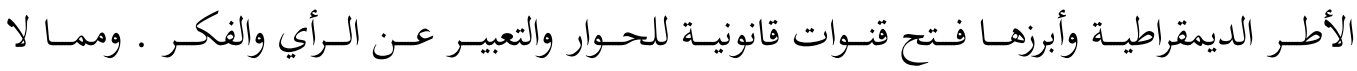
شـك فيـه أن فقـدان الحيـاة الديمقراطيـة الحقيقيـة يـؤدي إلـى تهمـيش بعـض الفئـات اجتماعيًا وسياسـيًا واسـتبعاد الأقليـات والفئـات المعارضــة وحركـات الـرفض ، ويخلـق جــوًا مـن الشـعور بالظلم ، ويدفع هؤلاء المظلومين إلى الانخراط في العمل السياسي العنيف .

\section{أزمة التعليم ومؤسساته}

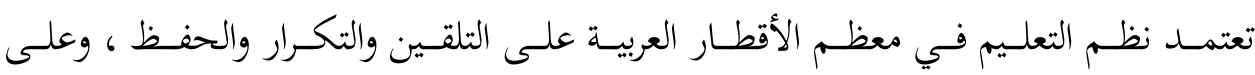
حشــو ذهـن الطالـب طـوال مختلـف المراحـل الدراسـية بمعلومـات ، دون إعمــال للعقـل ودون تحليـل أو نقـــ ـ ومثـل هـذه الـنظم تفـرز طالبَـا يتقبـل بسـهولة كـل مـا تمليـه عليـه سـلطة المعلـم دون نقـاث ، وبــلك يصـبح مـن السـهل جـدًا علـى مثـل هـذا الطالـب أن يتقبـل كـل مـا تمليـهـ عليـه سـلطة أميـر الجماعـة دون تحليـل أو نقــد أو معارضــة ، ويكـون عرضـة للانخــاط في أيسة جماعـة أيًا كــان توجهرهـا ، حيـث يـتم تلقـين الفكـــ وتقبلـه دون تحليـل ، ويسـهل الانقيـاد بفعل إبطال عمل العقل 7. الفراغ الفكري والفهم الخاطئ للدين 


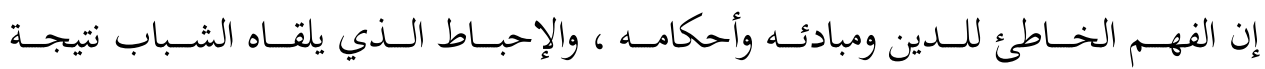
افتقـارهم إلـى المثـل العليـا التـي يؤمنـون بهـا في سـلوك المجتمـع أو سياسـة الحكـم ، والفـــاغ

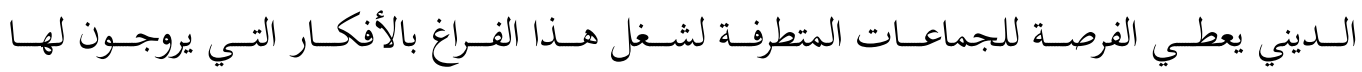

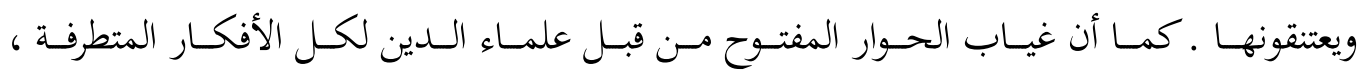
ومناقشـة الجوانـب التـي تـؤدي إلى التطرف في الـرأي يرسـخ الفكـر المتطـرف لـدى الشـباب .

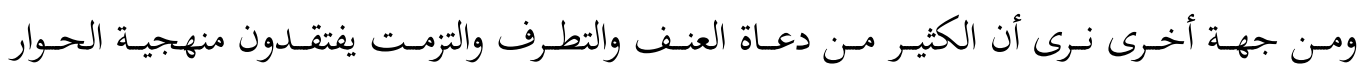

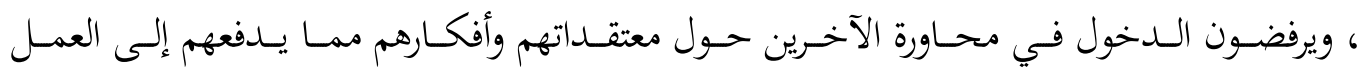
السري.

V. التشدد والغلو في الدين

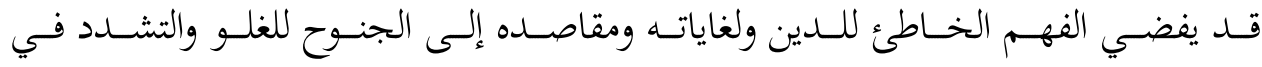

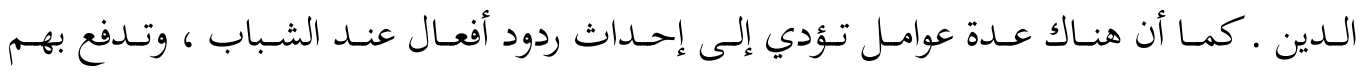
إلـى التشــد والغلـو ، منهــا اسـتفزاز المشــاعر الدينيــة مـن خـلال تسـفيه القـيم أو الأخــاق أو

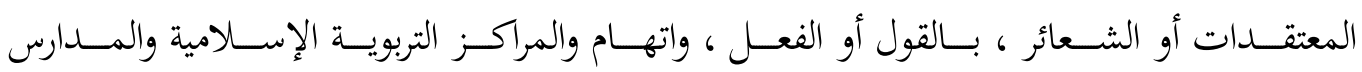

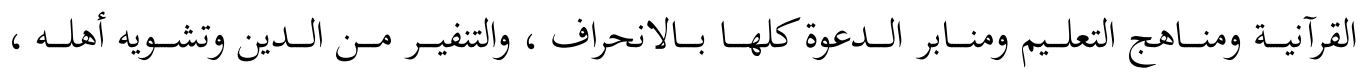

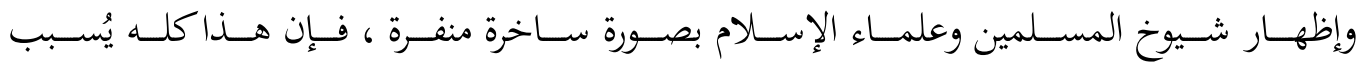
التطـرف والغليـان خاصـة فـي نفـوس الشـباب الـذين يقـرؤون ويسـمعون الاتهامـات الكاذبــة

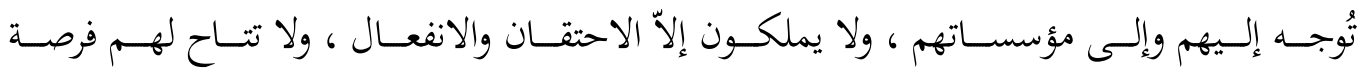
ل للرد7 17

ويتبـع الإعـلام الغربـي سياسـة تبعـــ عـن العــل والإنصــاف ، عنــدما يـتهم مناهجنــا وثقافتنـا الإسـلامية ويعيبهـا بأنهـا ترسـخ في أبنائنـاكراهيـة الآخـر ومناصـبته العـداء ، في الوقـت

1ا** التل (أحمد يوسف) ، الإرهاب في العالمين العربي والغربي ، عمان - الأردن ، ط ا ، 991 ام ص 
Al-Hikmah. Vol, 18 No. 1 April 2020

الـذي لا يسـلط فيسه الضـوء على نظـرة الغـرب إلى المسـلمين الـــين هـم فـي الثقافـة والمنــاهج الدراسـية الغربيــة ، ســفاحون وإرهــابيون ومحــــاربون متطرفــون ومضـــهـون للمــرأة ويعتنقــون

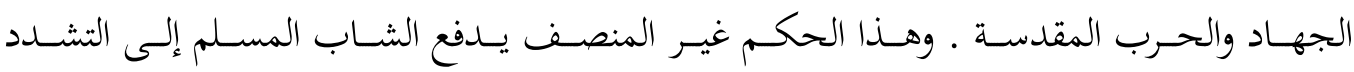
والغلو واتخاذ موقف المدافع عن دينه وعقيدته ـ 9. سياسات الهيمنة الأجنبية مـن الأسـباب الرئيسـة فـي تغذيسة التطرف الـديني والإرهـاب في الـبلاد الاسـلامية هـو الممارســات الاسـتعمارية الاسـتيطانية الصــهيونية فـي فلســـين المحتلـة ومــا جاورهــا ـ وهــي تـؤثر بشـكل مباشـر في ملايسين مسن العـرب الـواقعين تحست الاحستلال الإسـرائيلي في فلسـطين والجولان السورية ، ومن ثم في البلاد في مختلف في البلاد الاسلامية. إن مشــاعر الإحبــاط واليــأس عنــد الكثيــر مــن المســلمين وخاصــة الشــباب الملــيء

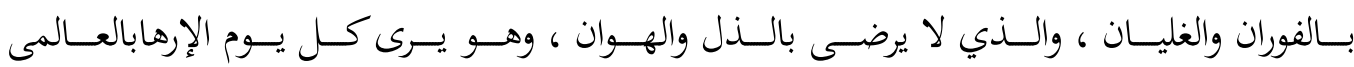
وتسـلطه علـى العـالم الإسـالمي دون احتـرام لأنظمـة عالميـة ، ولا قـرارات دوليـة ، ويسرى كـل يـوم الإرهــاب الصـهـيوني وإذلالـه وقتلـه للشـعب الفلســيني دون أن يكــون هنـاك ردود أفعـال جــادة مـن الحكومـات العربيـة ، كـل هـذه الأسـبـاب وغيرهـا هـي واقـع يعيشــه المسـلم ، فـي

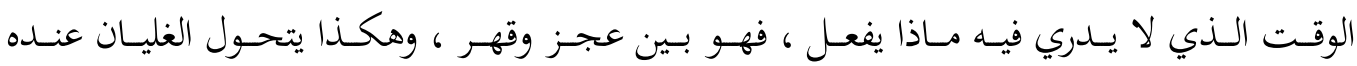
إلى غلو وتطرف ، مما يجعله يبحث عن حلول عاجلة وسريعة لتغيير واقع الأمة .

\section{المبحث الثالث: سبل مواجهة الإرهاب}

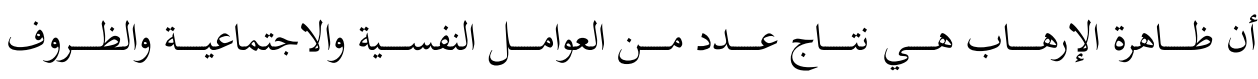

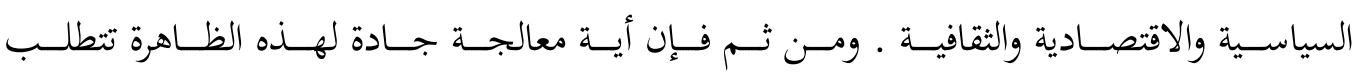

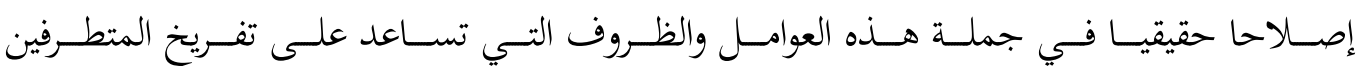
والإرهـابيين • وفهـم ظـاهرة الإرهـاب في أي مجتمـع ، يتطلـب فهـم الواقـع الاجتمـاعي وإدراكـهـ ، حتـى يتســى لنـا معرفـة الآليـة التـي تنـتج هـذه الظـاهرة . والجـــير بالـذكر أن المجتمعـات التي يكـون فيهـا حـــ مـن المســاواة والعدالـة وتتسـع فيهـا المشـاركة في تقاسـم الإنتـاج والثـروة ، 6 


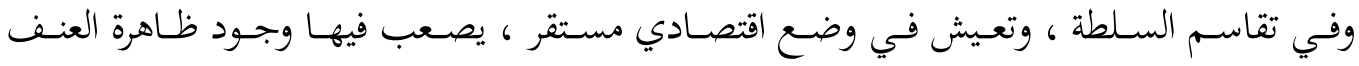
والإرهاب.

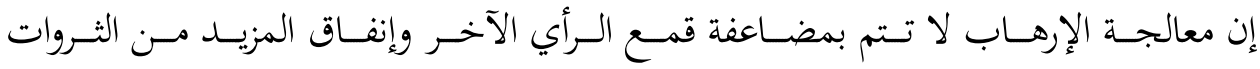

على تسـليح قـوات مكافحــة الإرهـاب بأحســث معــات القتــال ، بـل بــالوقوف على الأسـباب

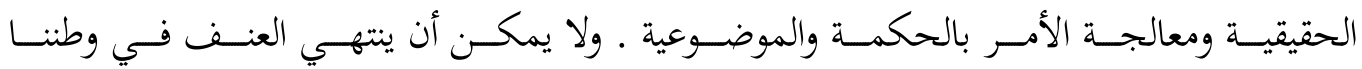
العربـي وعالمنــا الإسـلامي إلا بقيـام البــائل الديمقراطيـة التـي ترتكـز على مؤسســات دسـتورية تحتــرم المـواطن وتشـاركه القـرار وترفـع مسـتواه الاقتصـادي والاجتمـاعي والثقـــي وتقلـل الفـوارق

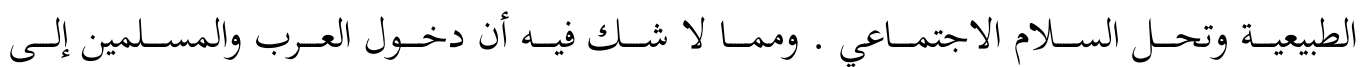

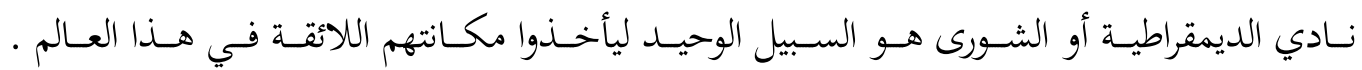
ويمكننـا رسـم سياسـة عامـة لهـذه المواجهـة فـي سـبيل الوقايـة مـن التطـرف ، والعـلاج مـن الإرهاب V، وذلك على النحو الآتي :

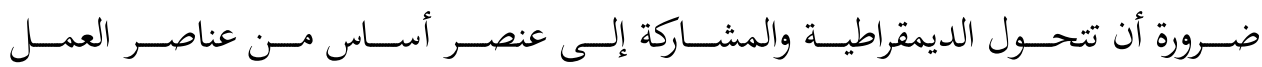

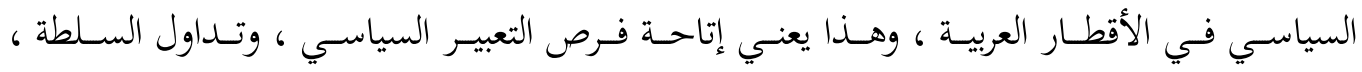
ونزاهة الانتخابات ، وممارسة الرقابة الشعبية . التعـرف علـى تجــارب بعـض الأنظمـة العربيـة فـي التعامـل مـع التيــارات الإســلامية

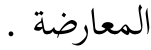

ضــرورة أن يـؤدي المثقفـون العـرب عمـلًا تنويريًا حقيقيَّا لا يقتصـر فتـط على المقــالات والأعمدة الصحفية ، بل يجب أن يتحول جهدهم إلى ممارسات شعبية حقيقية .

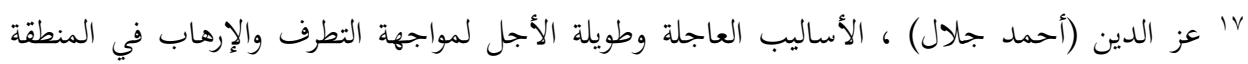

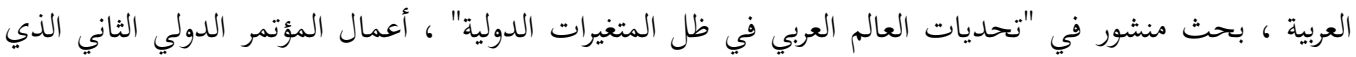

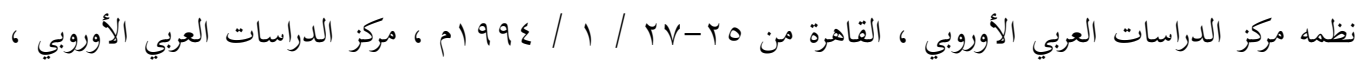


Al-Hikmah. Vol, 18 No. 1 April 2020

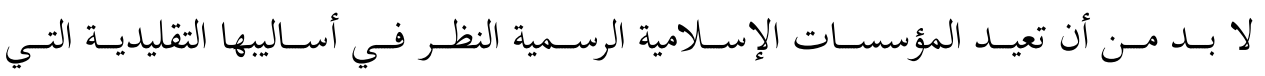

اعتـادت عليهـا فـي مجــالات الـوعظ والإرشـاد والتوجيـه ، وأن تتحــول إلىى مؤسســات فعالـة قـادرة على تقــديم إجابـات عـن تســاؤلات الحيـاة المعاصـرة ، ومســاعدة الإنســان العربسي على

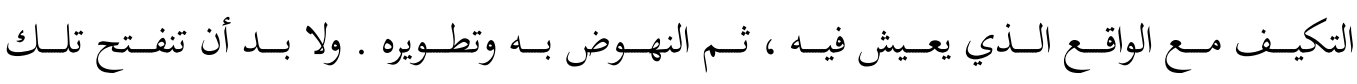
المؤسسـات على العـالم الخـارجي ، وتــير في الوقـت نفسـه حـوارًا حقيقيَّا مـع التيـارات الدينيـة المختلفة في الوطن العبي .

تحتـل البـرامج التعليميـة مكانسة خاصـة فـي أيسة إسـتراتيجية لمواجهـة التطـرف والإرهـاب

• مـن الضــروري أن تتضـمن البـرامج التعليميـة قـيم الحـوار ، والنقـــ ، والتعـايش ، وإقـرار حقـوق

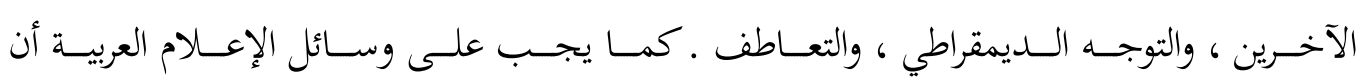

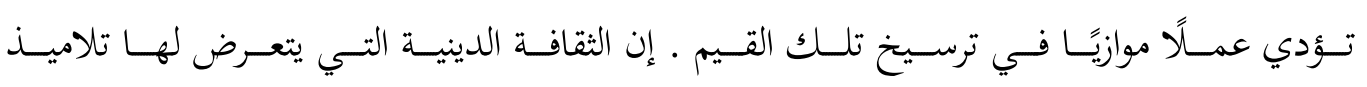
المــارس ، والمقـررات الدينيـة المقـررة في مدارسـنا تحتــاج إلى مراجعـة دقيقـة . كمــا نـدعو إلى

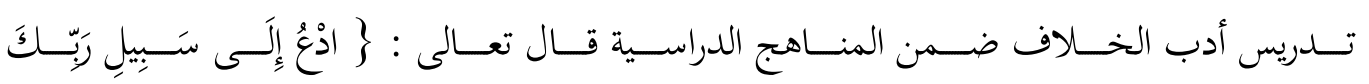

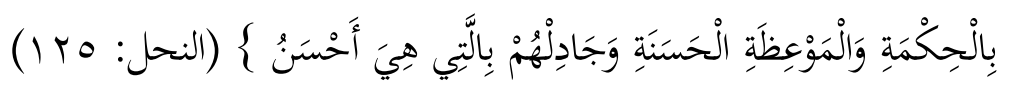
إعــادة النظــر فـي تراثنــا العربـي والإســالامي ، بمـــا يضــمن قـيم التعدديـة السياسـية 6 والحريـة الفكريـة ، وإبــراز دور المـرأة ، والثـورى ـ إن المجتمـع الإسـلامي في الجانسب الأكبـر مـن تاريخـه كـان يقـر التعدديـة وذلـك إذا نظرنـا إلى الملل والطوائسف التـي كـان يضـمها ، والتـي كانت تتعايش معًا دون تناقض ظاهر . إن الحــوارات الوطنيـة فـي الأقطسار العربيـة مطلسب ضــوري ، لأنهـا تضـمن توثيـق الصـلة

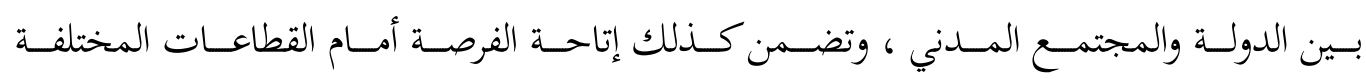
للإسهام بنصيب في صياغة التوجهات السياسية ، والمشاركة في مواجهة أزمات الأمة.

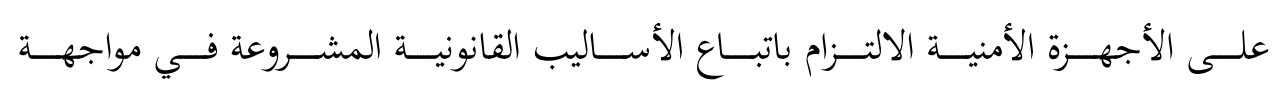

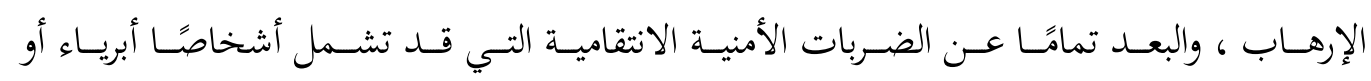

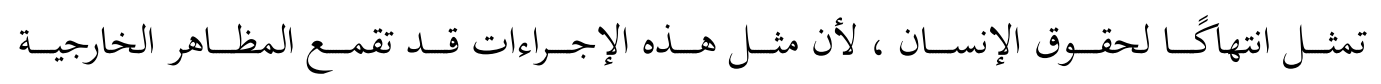




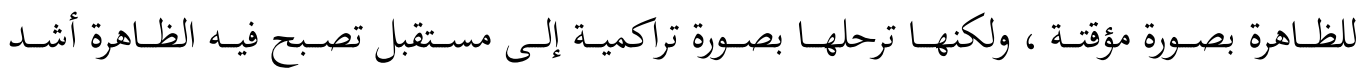
خطورة وأكثر استعصاء على الحل .

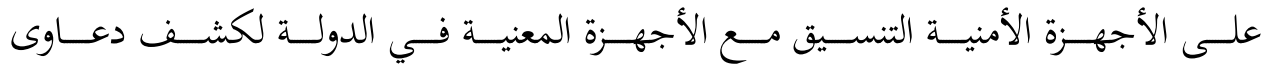

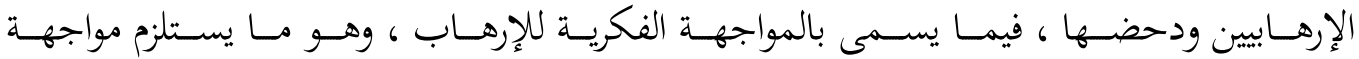

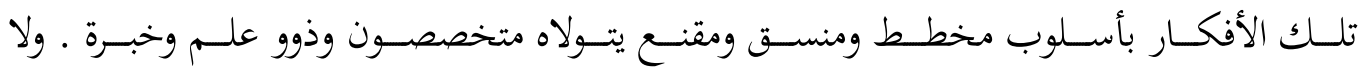

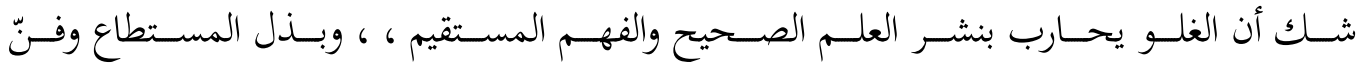

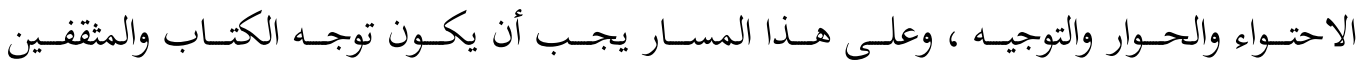

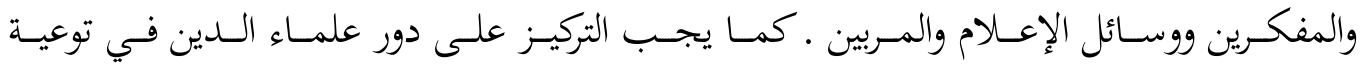

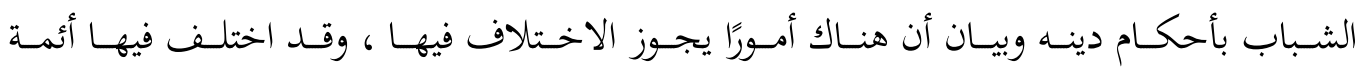

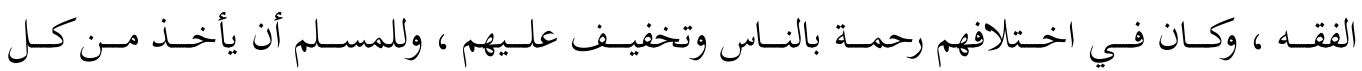
مذهب دون أن يكون في ذلك خروجٌ .

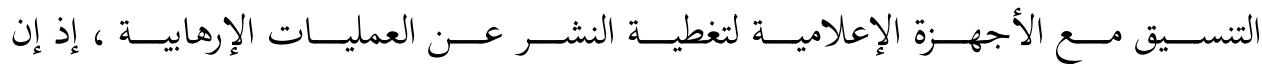

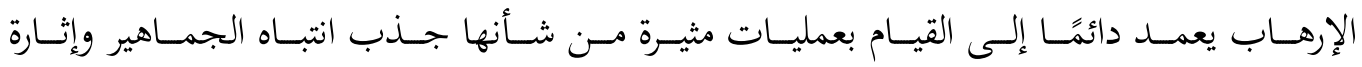
الرعـب العـام ، وغالبَّا مـا تسـتدرج وسـائل الإعـام إلى التغطيـة المكثفـة للنشـاطات الإرهابيـة ،

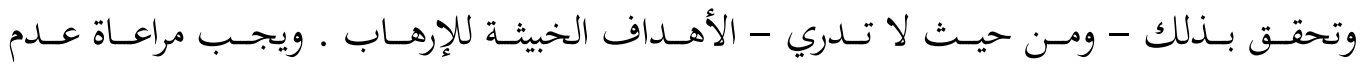

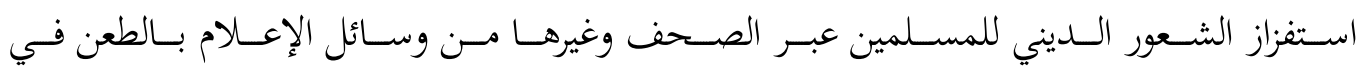

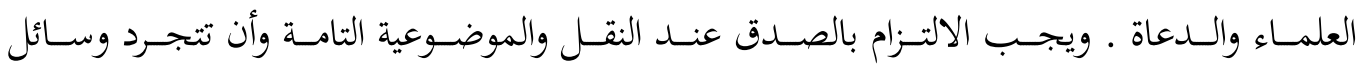
الإعـلام عـن الإتـارة أو المبالغـة والتهيسيج والتـأجيج ، ويكــون التضـخيم والتحقيـر فـي حسـود

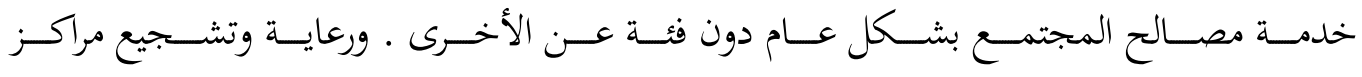

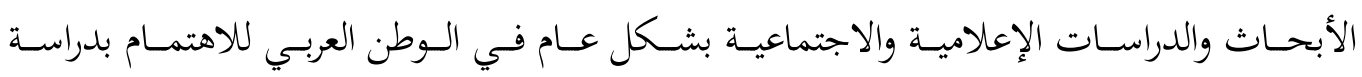

الإعلام الإرهابي والإرهاب الإعلامي · (1)

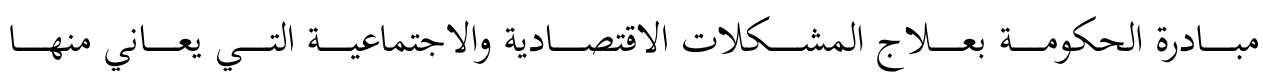

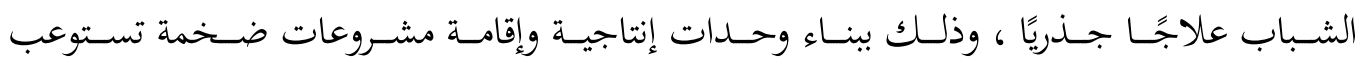


Al-Hikmah. Vol, 18 No. 1 April 2020

أعدادًا كبيرة من الشباب حتى يمكن توفير فرص العمل والقضاء على البطالة .

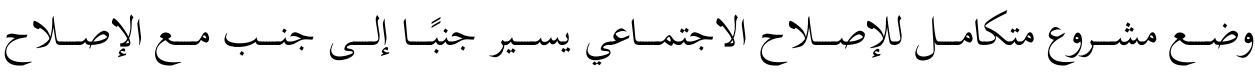

الاقتصـادي ، ويهــف هـذا المشـروع إلى إصـلاح أوجـه الخلـل الموجـودة في مختلـف الـنظم الاجتماعية وهذا هو دور الحكومة .

تخفــيض مثيـرات التطـرف والعنـف إلى أدنسى مســتوى وذلـك مـن خــلال منـع الظلـم

علـى المســتوى الفــردي والاجتمــاعي ، وإرســاء العـــل ومنــع تفشـي الفــواحش والمنكـــرات وإرساء قواعد التكافل الاجتماعي ومحاربة الفساد .

على الجميـع وبــالأخص العلمـاء والــلعاة والمربـون واجــب عظـيم فـي بيــان الحـق

للشـباب ، ووصـف طريـق الصـواب ـ وتوعيـة الناشـئة وتبصـيرهم بسـلامة المـنهج ، والشـباب بـأمس الحاجـة اليـوم لمسن يفـتح قلبـه لهـم ، ويجلـس إلـيهم ، ويسـمع مــهم ، ويلـين القـول لهـم ، بدل أن تُعلق الأبواب في وجوههم ، وتعصف بهم الشبهات والضلالات . المشـاركة السياسـية للشـباب مـن مختلـف الطبقـات ، في اتخــاذ جميـع القـرارات التسي تمس حياة المواطن سواء داخل الأسرة أو المدرسة أو السكن ·. يجــب أن يتجــه الواقـع التربـوي إلـى تعلـيم الطفـل كيـف ينـاقش ، وكيـف يعبـر عـن رأيسه بحريـة ، وكيـف يحتــرم آراء الآخـرين ، وكـذلك يجـب التركيـز على فلسـفة المشــاركة في جميـع

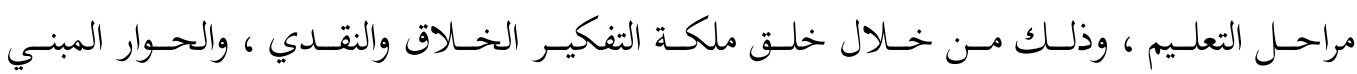
علـى التحليــل والاسـتنباط ، واحتــرام الـرأي الآخــــ ، والإيمــان بالمشــاركة الفعالـة فـي قضــايا

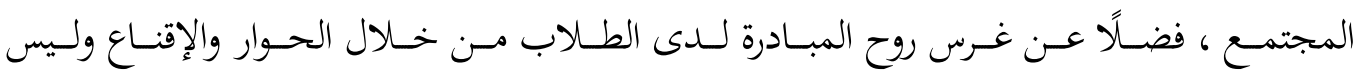

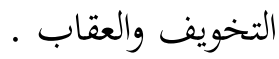

تـــعيم المشـاركة الشـعبية التـي تقتضـي ضــرورة القضــاء على البطالـة ومواجهـة مشـكلة

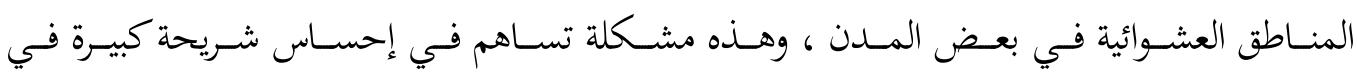
المجتمـع بأنهـا تعـاني مـن إهمـال وتجاهـل الدولـة ، الأمـر الـذي يـنعكس سـلبًا على أثترهم في

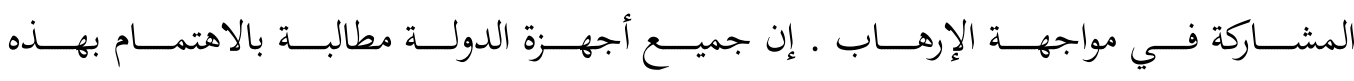


المجتمعات العشوائية والنهوض بها اجتماعيًا واقتصاديًا وثقافيًا . .

ضــرورة العمـل علـى تكــريس الشـورى أو توزيـع سـلطة اتخــاذ القــرار فـي كـل منــاحي

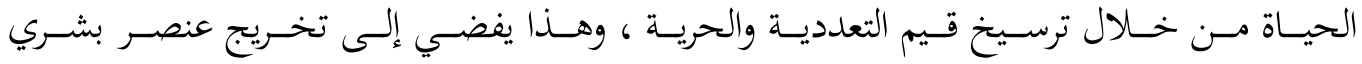

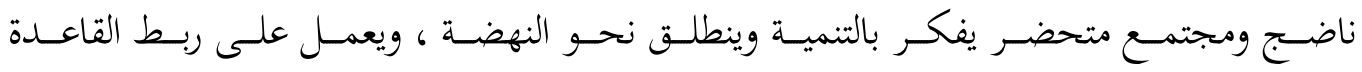

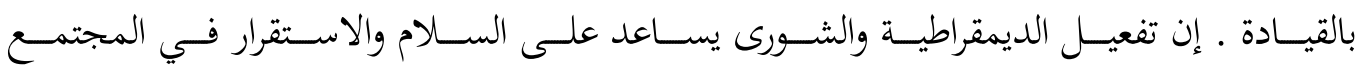

ويبعد شبح العنف بصورة متزايدة .11

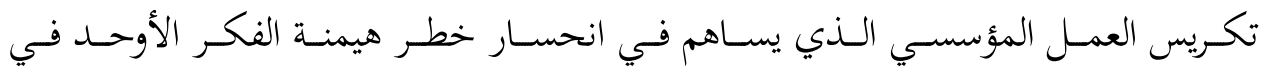

الســاحة ـ وهــــه المؤسســات هـــي مجـــالس البرلمانــات والثــورى والأحســـاب السياســية وجماعـات المصـالح والجمعيـات النفعيـة وجمعيـات الخــدمات وجمعيـات المجتمـع المــني والمؤسسات أو الجمعيات والنقابات المتخصصة في مجالات عمل معينة .

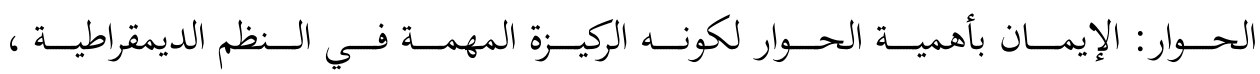
والاعتـراف بحـق الآخـــ في التعبيـر عـن رأيـه ووجهـة نظــه ـ إن فـتح قنـوات الحـوار أمـر إيجـابي حيـث يضـع المتطـرفين والإرهـابيين فـي دائـرة النفكيـر بصـوت عـال مـن ناحيـة ، ويضـع فكـر ومعتقدات التطرف تحت مطارق النقد والمصارحة والمكاشفة من ناحية أخرى . يجـب الاهتمـام بتكـريس القـيم الأخلاقيـة في العمـل السياسـي والإسـلامي ـ ومـن أهـم

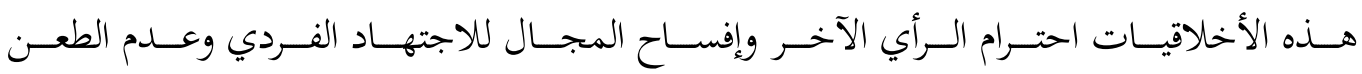
والتجريح ضد المخالف في المنهج أو الموقف السياسي .

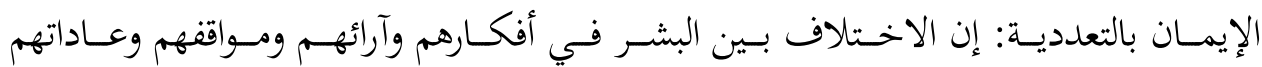

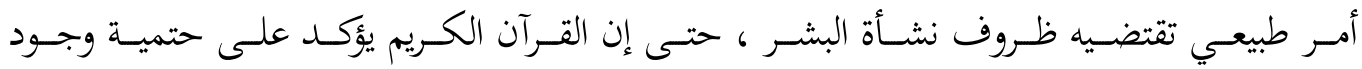

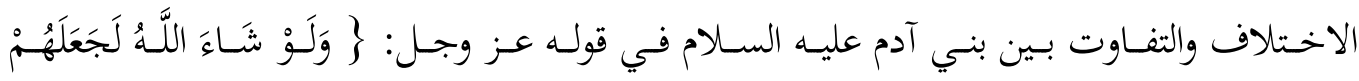

^`عز الدين (أحمد جلال) ، الأساليب العاجلة وطويلة الأجل لمواجهة التطرف والإرهاب في المنطقة العربية

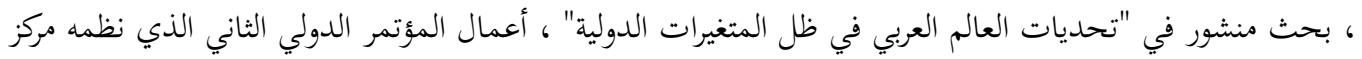

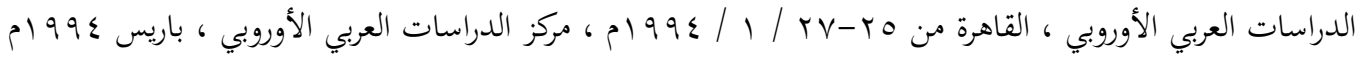


Al-Hikmah. Vol, 18 No. 1 April 2020

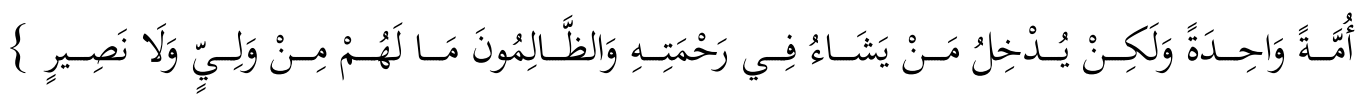

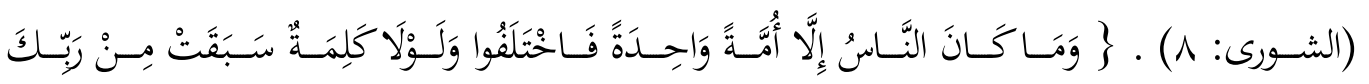

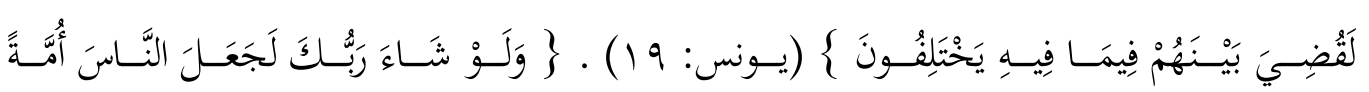

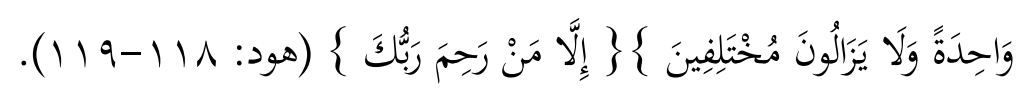

\section{المبحث الرابع: الخاتمة}

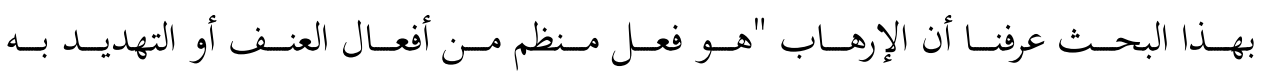

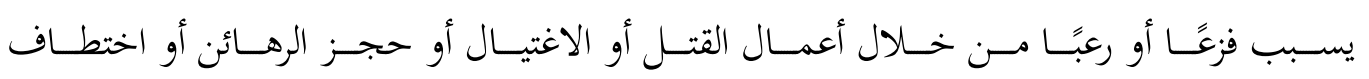

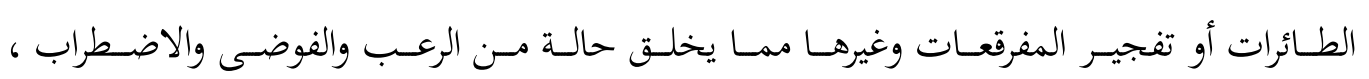

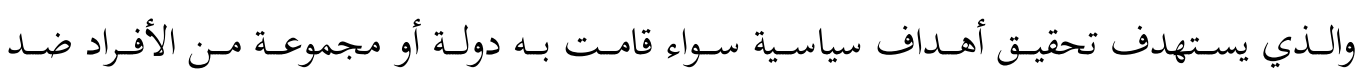

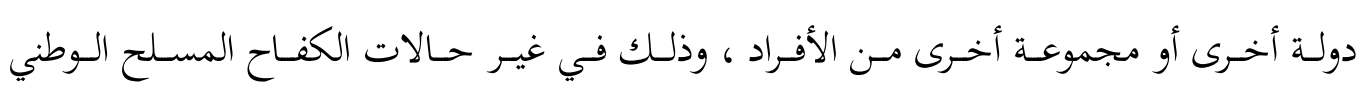

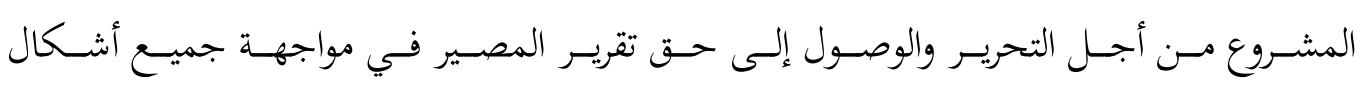

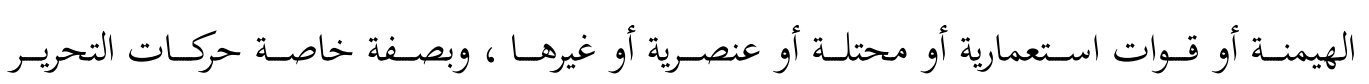

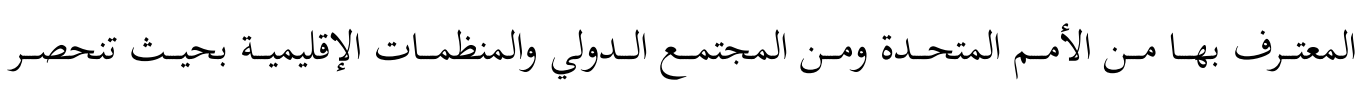

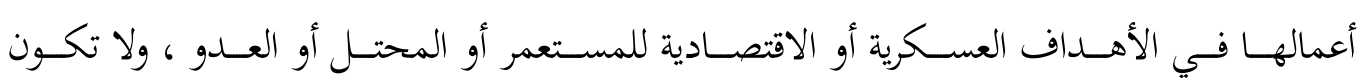

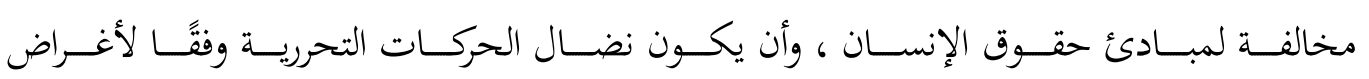
ومبادئ ميثاق الأمم المتحدة وسواه من قرارات أجهزتها ذات الصلة بالموضوع".

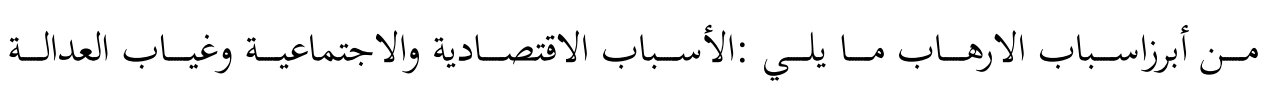

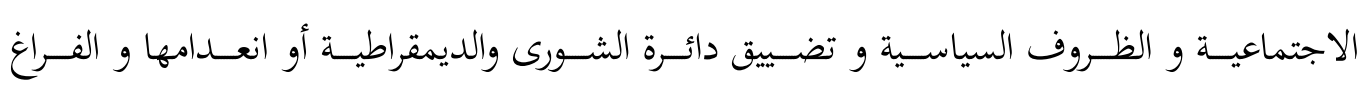
الفكري والفهم الخاطئ للدين و التشدد والغلو في الدين

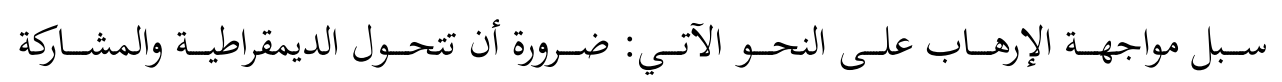




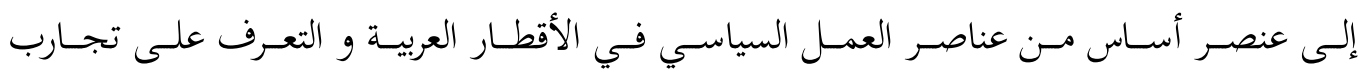

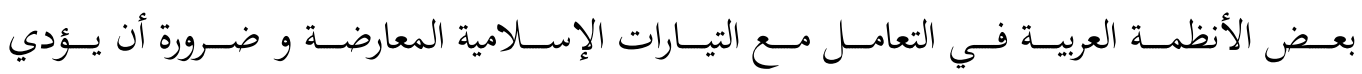

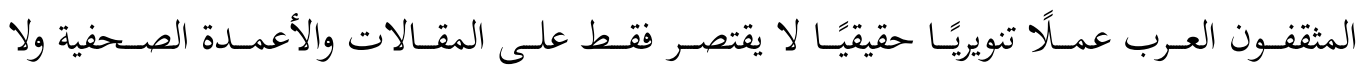
بـــ مـن أن تعيـــ المؤسسـات الإسـلامية الرسـمية النظــر فـي أسـاليبها التقليديـة التسي اعتـادت عليهـا في مجـالات الـوعظ والإرشـاد والتوجيـه و تحتـل البـرامج التعليميـة مكانـة خاصـة في أيسة

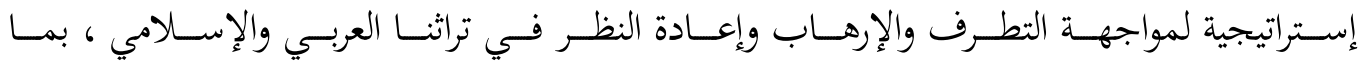
يضـمن قــم التعدديـة السياسـية ، والحريـة الفكريـة ، وإبـراز دور المـرأة ، والشــور وإن الحـوارات الوطنية في الأقطار العربية مطلب ضروري.

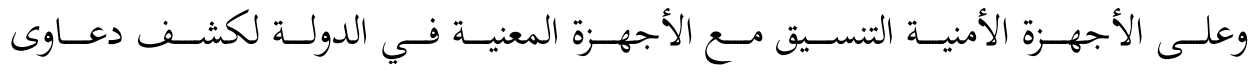
الإرهـابيين ودحضـهـا ، فيمـا يسـمى بالمواجهــة الفكريـة و التنسـيق مـع الأجهــزة الإعلاميــة لتغطيـة النشـر عـن العمليـات الإرهابيـة و مبـادرة الحكومــة بعـلاج المشـكلات الاقتصـادية

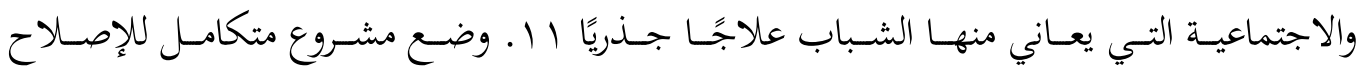
الاجتمـاعي يسـير جنبَّا إلـى جنـب مـع الإصـلاح الاقتصـادي ، ويهـدف هـذا المشـروع إلـى

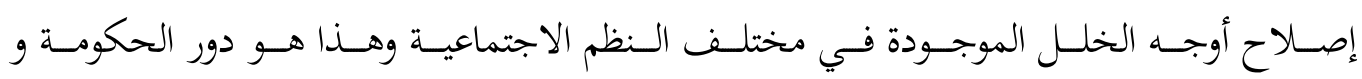
تخفـيض مثيـرات التطــرف والعنـف إلـى أدنـى مســوى و علـى الجميـع وبــالأخص العلمــاء والـدعاة والمربـون واجـب عظيم في بيـان الحـق للشـباب ، ووصـف طريـق الصـواب ـ وتوعيـة

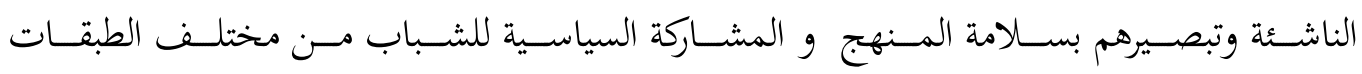
وتـدعيم المشـاركة الشـعبية التـي تقتضـي ضـرورة القضــاء على البطالـة ومواجهـة مشـكلة المنـاطق العشـوائية في بعض وضـرورة العمـل على تكـريس وتكـريس العمل المؤسسي الـذي يسـاهم في انحسـار خطر هيمنـة الفكـــ الأوحـــ في السـاحة و الحـوارو الاهتمـام بتكـريس القـيم الأخلاقيـة في العمل السياسي والإسلامي و الإيمان بالتعددية 
Al-Hikmah. Vol, 18 No. 1 April 2020

\section{المراجع والمصادر}

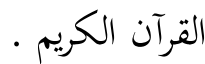

ابـن كثيــر (الحــافظ عمـاد الــين أبـو الفــداء إسـماعيل) ، تفسـير القـرآن العظسيم ، ج ج ، دار

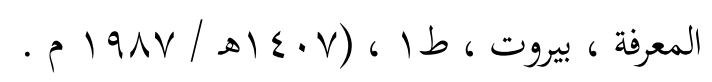

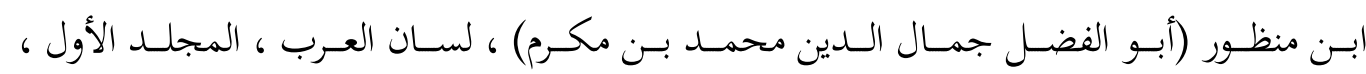

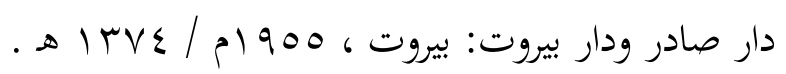

البعلبكـي (منيـر) ، المـورد- قـاموس إنكليـزي عربـي ، دار العلـم للملايسين ، بيـروت ، ط اب ، . $199 \mathrm{~V}$

التـلـ (أحمـــ يوسـفـ) ، الإرهـاب فـي العـالمين العربـي والغربـي ، عمــان - الأردن ، ط | ، - 1991

الجاسـر (عبـــ اللـه) ، دور وسـائط الإعـام فـي مواجهـة التطـرف والإرهـاب ، بحــث منشــور فـي "تحـــيات العـالم العربـي فـي ظـل المتغيـرات الدوليـة" ، أعمـــال المـؤتمر الــدولي

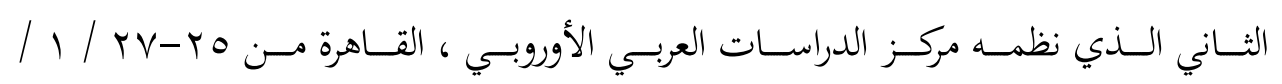

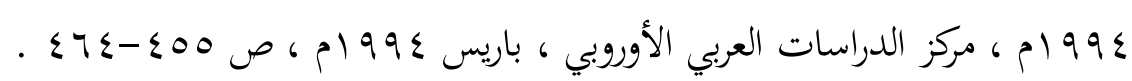
الحسـيني (السـيد محمــد) ، تعقيـب في "تحــيات العـالم العربـي في ظلـ المتغيـرات الدوليـة" ، أعمـال المـؤتمر الــولي الثـاني الـــي نظمـهـ مركـز الدراســات العربـي الأوروبـي ، القـاهرة

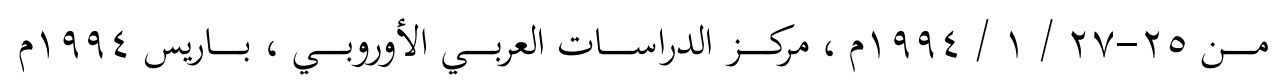
. $\Sigma \vee \wedge-\varepsilon \vee \cdot ص 6$

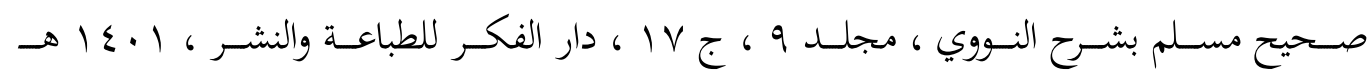
p $1911 /$ 


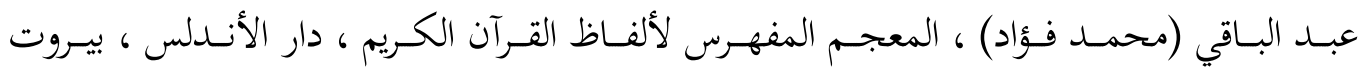

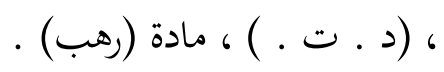

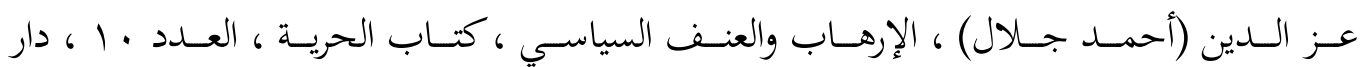

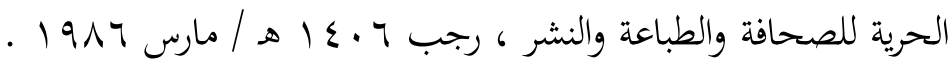

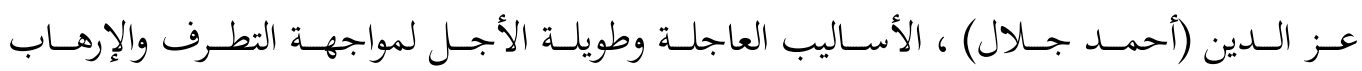
في المنطقـة العربيـة ، بحـث منشـور في "تحـــيات العـالم العربـي في ظـل المتغيـرات الدوليـة" ، أعمــال المـؤتمر الــدولي الثـاني الـذـي نظمـه مركـز الدراسـات العربـي الأوروبـي

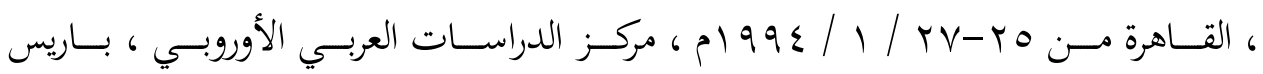
$. \varepsilon 0 \varepsilon-\varepsilon \cdot 0 \cdot$. $19199 \varepsilon$

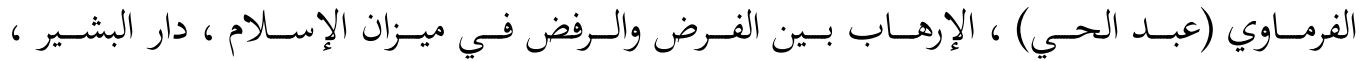
. p

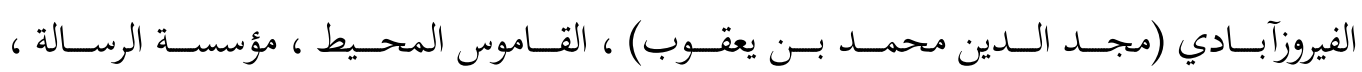

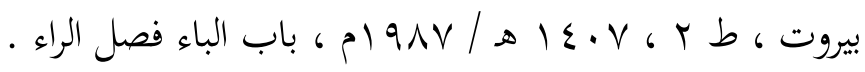

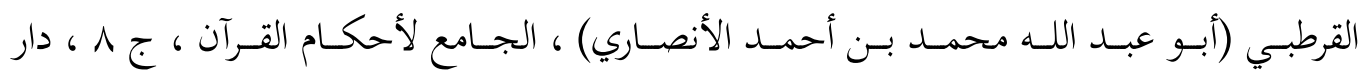
إحياء التراث ، بيروت ، 0 . ع أهـ /

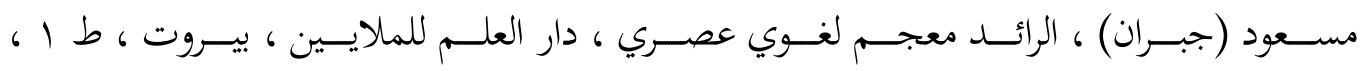
- $197 \mathrm{~V}$

المعجـم الوسـيط ، دـ ـ إبـراهيم أنسيس وآخـرون ، ج ا ، ط ب ، مجمـع اللغـة العربيـة ، القــاهرة

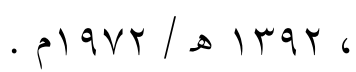

المنجد في اللغة ، دار المشرق ، بيروت ، ط 9 9 ، 9191 ام . Oxford Universal Dictionary, Compiled by Joyce M. Hawkins, Oxford University Press, Oxford, 1981. 
Al-Hikmah. Vol, 18 No. 1 April 2020

Principles, revised and Edited by C. T. Cnions, 3rd Ed. , Oxford: The Clarendon press, 1959

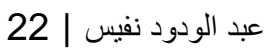

